http://heanoti.com/index.php/hn

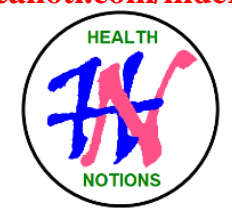

RESEARCH ARTICLE

URL of this article: http://heanoti.com/index.php/hn/article/view/hn301210

\title{
Aromatherapy Cajuput Oil for Emesis Gravidarum
}

\section{Eny Pemilu Kusparlina}

Muhammadiyah Midwifery Academy of Madiun, Indonesia; pemilu77@yahoo.co.id (Corresponding Author)

\begin{abstract}
Emesis Gravidarum can be very disturbing activity and impact on the maternal and fetal maternal obstacles. The incidence of emesis gravidarum in the world is $70-80 \%$ of the number of pregnant women, one nonpharmacological method that can reduce the intensity of nausea vomiting by cajuput oil. This research purposes to determine whether there is an influence of aromatherapy cajuput oil on emesis gravidarum in the first trimester pregnant women. This research used cross sectional approach. Population in this research is the first trimester pregnant woman which amounted to 17 pregnant women taken by using total sampling. The data were analyzed by univariate analysis with independent variable frequency distribution and dependent and bivariate analysis using Wilcoxon sign rank test. P-value value: 0.000 and alpha 0.005 Statistical test results show that cajuput oil has a significant effect on emesis gravidarum intensity. It can be concluded that there is an effect of Aromatherapy cajuput oil on emesisgravidarum in the first trimester pregnant woman, so it is expected that cajuput oil can be one of alternative non pharmacological method that can help to reduce the intensity of emesis gravidarum.
\end{abstract}

Keywords: Pregnancy, Emesis gravidarum, Cajuput oil

\section{INTRODUCTION}

\section{Background}

Nausea and vomiting of pregnancy (NVP) is one of the most common disorders of pregnancy. The symptoms occur predominantly during the first trimester, although in a subgroup of patients they can continue throughout the entire pregnancy and can affect the woman's quality of life. A small percentage of women develop a severe form of NVP called hyperemesis- Nausea rate of vomiting in the world that is $70 \%-80 \%$ of pregnant women. Half of pregnant women experience nausea of vomiting even just because it smells certain foods only. Pregnancy is the union of male and ovum sperm from women. The period of pregnancy starts from conception until the birth of the fetus. The duration of normal pregnancy is 280 days (40 weeks or 9 months 7 days) calculated from the first menstrual period last. Pregnancy is divided into three quarters ie first quarter starting from conception to 3month, second trimester from 4th to 6th month, 3rd quarter from 7th to 9th month Symptoms commonly occur in the first trimester pregnant women is nausea vomiting (emesis gravidarum). Nausea and vomiting of pregnancy (NVP) is a very common disorder reported in 70-80\% of pregnant women ${ }^{(1)}$.

Nausea (nausea) and vomiting (emesis gravidarum) are common symptoms and are often found in the first trimester pregnant women. Nausea usually occurs in the morning (morning sickness) but can also arise at night. This symptom occurs approximately 6 weeks after First Day of Menstruation Last and lasts for approximately 10 weeks. Almost 50-90\% of pregnant women experience nausea vomiting in the first trimester. Nausea vomiting occurs in $60 \%-80 \%$ primi gravida and $40 \%-60 \%$ in multi gravida. These symptoms will become more severe in 1 in 1000 pregnancies. The typical pregnancy nausea and vomiting occurs during the first trimester and is most easily caused by an increase in the amount of HCG. Nausea is also associated with changes in the sense of smell and feeling in early pregnancy. Nausea is also associated with changes in the sense of smell and feeling in early $\operatorname{pregnancy}^{(2)}$.

Based on the survey data on March, 2018 at Clinic Mrs S Madiun city, found the number of pregnant women as many as 24 people, and the first trimester pregnant women who experienced nausea vomiting as many as 18 people. This shows the high incidence of nausea as many as 16 people (90\%) knowledgeable mild nausea, 2 people (10\%) experienced moderate nausea. The high incidence of nausea in the first trimester pregnant women in Clinic Mrs S Madiun city, the researchers are interested to conduct research at Clinic Mrs S Madiun city in 
2018.

This feeling of nausea is caused by increased levels of the hormone estrogen and HCG (Human Chorionic Gonadrotropin), this placenta hormone can trigger a nausea center that is chemoreceptor trigger zone so that cause nausea and vomiting during pregnancy. The increase of estrogen hormone and the decrease of hormone TSH (Thyrotropin Simulting Hormone) of these three hormones is believed to be some of the factors that have an effect on nausea of vomiting in pregnancy ${ }^{(3)}$. Nausea and vomiting are the most common disorders we encounter in young pregnancies and are expressed by $50-70 \%$ of pregnant women.

The physical and emotional impact of NVP often results in anxiety and concern about possible fetal effects $^{(4)}$. Nausea and vomiting during pregnancy negatively impacts family relationships and has major consequences on the pregnant woman's working capabilities ${ }^{(9)}$. The cause of nausea and vomiting during pregnancy is still unknown. Therefore, wide varieties of treatment have been used empirically. Prescription drugs are usually avoided in early pregnancy due to concern for potential teratogenic effect. Vitamin B6 is frequently used as a first line treatment for pregnant women experiencing nausea and vomiting. However, a large number of pregnant women require additional drugs, such as dimenhydrinate and promethazine ${ }^{(5,6)}$. The cortisol levels in primiparaous postpartum women who receive treatment massage, aromatherapy, aromatherapy massage and control group was significanly different before and after the treatment. These drugs may cause side effects such as sedation, mouth dryness, motor weakness and visual disturbance. Because of concern about pharmaceuticals in early pregnancy, non-pharmaceutical management is increasingly used to minimize nausea and vomiting in pregnancy ${ }^{(7)}$. The use of complementary therapies in mainstream medicine is increasing. Maternity health care providers are responding to this by incorporating these therapies into models of care within their services. Two national surveys in the USA reported the highest complementary and alternative medicine (CAM) uptake among women of reproductive age One of the most popular forms of complementary therapy is aromatherapy. Aromatherapy is the name given to a unique branch of herbal medicine that uses the medicinal and therapeutic properties of the oils found in various plants Actually, essential oils can be used in ${ }^{(8,9)}$.

Aromatherapy massage therapy can reduce anxiety and stress, as well as beneficial to the immune system $^{(10)}$. Aromatherapy dates back thousands of years to the ancient cultures of Egypt and India Although it is one of the lesser-known alternative therapies in the United States, nonconventional therapies are commonly practiced in Germany, France, Australia, Finland, Canada, and the United Kingdom. The American Society of Peri Anesthesia Nurses (ASPAN) Evidence-Based Clinical Practice Guideline for the Prevention and/or Treatment of PONV and Post Discharge Nausea and Vomiting(PDNV) in Adult Patients recommends implementation of rescue interventions to include aromatherapy ${ }^{(11)}$.

Aromatherapy scents that are perceived through olfaction and transmitted to the body stimulate the brain and the lungs. They have a positive effect on many parts of the body and can improve metabolism, blood circulation, digestion and hormonal function. The discipline of aromatherapy appears to be based on a history of traditional use and anecdotal reports: there is unfortunately little scientific evidence for many of the claims made in aromatherapy ${ }^{(12)}$.

The solution of to overcome nausea of vomiting in pregnant women containing essential oil of $1-6 \%$, consisting of $50-60 \%$ anethole, about $20 \%$ fenkon, pinen, limonen, dipenten, felandren, metilchavikol, anisaldehid , Asamanisat, and $12 \%$ fat oil. The content of anetol has a distinctive aroma, so it is useful to treat stomach pain (heartburn), flatulence (karminatif), full feeling in the stomach, nausea, vomiting, and diarrhea. Aromatherapy provides a variety of effects for its inhaler. Such as calm, freshness, and even help pregnant women overcome nausea ${ }^{(13)}$.

Aromatherapy is a therapeutic action by using essential oils that are useful to improve the physical and psychological conditions so that the better. Each essential oil has a unique pharmacological effect, such as antibacterial, antiviral, diuretic, vasodilator, tranquilizer, and adrenal stimulating ${ }^{(14)}$.The type of essential oil commonly used is cajuput oil, because the smell is sharp compared to other essential oils.Based on the above background, researchers are interested to examine the "Effect of aromatherapy Cajuput oil on emesis gravidarum in the first trimester pregnant women at Clinic Mrs S Madiun city 2018"

\section{Purpose}

This research purposes to determine whether there is an influence of aromatherapy cajuput oil on emesis gravidarum in the first trimester pregnant women.

\section{METHODS}

The method used in this study was the first interview. Conduct interviews directly to the respondents to access the frequency of nausea, Compare the frequency of nausea before and after aromatherapy cajuput oil. Second is observation. Researchers conducted study of nausea level before using aromatherapy cajuput oil, After examined respondents taught how to use aromatherapy cajuput oil way take 3 drops of oil cajuput oil drops on 
tissue and breathe 5-10 minutes. Aromatherapy in used 3 times a day for 1 week and is taught how to fill in the observation sheet according to which the responden experienced. The next is Collect to the first trimester pregnant women who have nausea vomiting, Next give the consent sheet to be the respondent (inform consent) to the first trimester pregnant woman who experience nausea, Giving explanation of the intent and purpose of the study the first trimester pregnant women who experience nausea, Giving an opportunity to respondent who are willing to follow the research sign the approval sheet to the respondent.

In this study population is all the first trimester pregnant women who experience nausea. The designs used in this study are described based on the scope of the study including inferential research types, based on research sites including field research type, based on data collection time including cross sectional design type, based on data collection including survey and observation type, based on data sources including primary, Based on the presence or absence of treatment including the type of pre experimental design with non equivalent control group design. In this study population is all the first trimester pregnant women who experience nausea in Clinic Mrs S Madiun city as many as 17 at the first trimester pregnant women. This analysis using statistic Wilcoxon rank test $^{(15)}$

\section{RESULTS}

Test Of hypothesis and analysis of data influences of about aromatherapy cajuput oil on emesis gravidarum on pregnant women.

Table 1. Distribution of data influences of about aromatherapy cajuput oil on emesis gravidarum on pregnant women.

\begin{tabular}{lccccc}
\hline Variables & \multicolumn{5}{c}{ Treatment } \\
\cline { 2 - 6 } & \multicolumn{3}{c}{ Pre } & \multicolumn{4}{c}{ Post } \\
\cline { 2 - 6 } & Median & Max-min & Median & Max-min \\
\hline Emesis Gravidarum & 4.00 & $5-2$ & 2.00 & $4-1$ & 0.000 \\
\hline
\end{tabular}

From result of research got result of median value before do research is 4.00 and max minimum value 52 , whereas result after done research is with median value 2.00 and minimum value $4-1$ in get P-value 0.000 . This show that aromatherapy cajuput oil can reduce the frequency of nausea in the first trimester pregnant women.

\section{DISCUSSION}

Frequency of nausea in the first trimester pregnant women before given aromatherapy cajuput oil most of the respondents experienced moderate nausea (64.70\%) and almost half of respondents in 6 respondents $(35.30 \%)$ intensity of nausea was in mild nausea.

According to researchers, nausea is a physiological discomfort in pregnancy, but frequent nausea with frequencies poses a danger. Nausea can cause disruption of daily activities, such conditions bring pregnant women to unpleasant situations. Seeing the effects of nausea can be said that nausea is one of the problems in the life of pregnant women who forced them to use various ways to prevent the occurrence of nausea in pregnancy ${ }^{(16,17)}$.

According to Mother's age affects how to make decisions in her health care. Healthy reproductive breeds are known that age is safe for pregnancy and childbirth is 20-30 years. Ages 20 and 30 are the ideal age for pregnancy and childbirth, while experts think women's age and physical affect the process of pregnancy, fetal health and childbirth. According to Nausea is an unpleasant feeling that usually spreads to the back of the throat, epigastrium or both and culminates in vomiting. Nausea is often accompanied by vasomotor symptoms of autonomic stimulation such as increased saliva, sweating, fainting, vertigo, tachycardia. also suggests the division of degrees of nausea include: mild nausea or sometimes vomiting is the most common form ${ }^{(18)}$.

Nausea appears as much as 1-3 times. Moderate nausea, symptoms can occur at any time of the day or night. The patient feels agonized and may be mildly dehydrated. Nausea appears as much as 4-6 times and interferes with activity so often rest. Nausea weight, Nausea persists and frequent vomiting, because it is called hyperemesis gravidarum. This woman is rapidly dehydrated and acidocetotic. Mom feels energized on the pit of the heart and nausea appears as much as 7 times or more so it is very disturbing activity takes a lot of time to rest. Nausea on this weight scale comes up suddenly - Arrive without triggering factors or unwelcome aromas ${ }^{(5,17,19)}$.

Identify the intensity of emesis gravidarum after being given cajuput oil in the first trimester pregnant women Clinic Mrs S Madiun city 2018. According to the researchers, the decrease in the level of nausea is influenced by the age level of a person, where the age of a person affects the ability of self to express the response or nausea, while usually at a young age is more sensitive to respond to nausea. Descent nausea patients caused by giving aromatherapy cajuput oil useful in Improves relaxation response and provides a sense of comfort that can inhibit the sensation of anxiety, fear, tension and distract from uncomfortable thoughts. Aromatherapy that 
can have a relaxing effect must have a strong aroma. The administration of the drug is expected to make the patient more focused on the inhaled scent not focusing on the invasive procedure it undergoes so that the patient feels relaxed ${ }^{(3,17,20)}$.

Aromatherapy cajuput oil also have properties to overcome nausea and vomiting in pregnant women. This is because it contains 1 to $6 \%$ essential oil, consisting of $50-60 \%$ anethole, about $20 \%$ fenkon, pinen, limonen, dipenten, felandren, methylchavikol, anisaldehid, asamanisat and $12 \%$ fatty oil. The content of anetol has a distinctive aroma, so it is useful to treat stomach pain (heartburn), flatulence (karminatif), full feeling in the stomach, nausea, vomiting, and diarrhea. Aromatherapy provides a variety of effects for its inhaler ${ }^{(21)}$.Such as calm, freshness, and even help pregnant women overcome nausea. Aromatherapy is a therapeutic action by using essential oils that are useful to improve the physical and psychological conditions so that the better. Each essential oil has a unique pharmacological effect, such as antibacterial, antiviral, diuretic, vasodilator, tranquilizer, and adrenal stimulating. The type of essential oil commonly used is cajuput oil, because the smell is sharp compared to other essential oils ${ }^{(22)}$.

Effect of aromatherapy cajuput oil on emesis gravidarum in the first trimester pregnant women in Clinic Mrs S Madiun city in 2018. According to researchers, aromatherapy cajuput oil can provide comfort and relaxation which is one way to reduce 'nausea. Aromatherapy cajuput oil can give compaseru, freshness and improve the physical and psychological conditions so that the better. Nausea in early pregnancy can be overcome by using therapeutic oil, also known as essential oil, is the result of distillation or distillation of eucalyptus leaves (Melaleuca Leucadenron Linn) which has a distinctive aroma and properties ${ }^{(13,23)}$. With its aroma and efficacy are efficacious, eucalyptus oil can function as an aromatherapy to relieve symptoms of nausea. As is known, one of the things that provoke the onset of nausea is the smell of unpleasant smells around pregnant women. By inhaling eucalyptus oil, nausea can be minimized. Beyond the function of aromatherapy, white eucalyptus that has a warm feeling can help warm pregnant women who tend to be more sensitive to cold air. It can also relieve stomach bloating, colds, and itching, which also often attacks pregnant women ${ }^{(22,24)}$.

\section{CONCLUSION}

There is an influence of the frequency of nausea before and after aromatherapy cajuput oil given to pregnant women of trimester 1 . So it is expected cajuput oil can be one alternative non-pharmacological methods that can help reduce the intensity of emesis gravidarum.

\section{REFERENCES}

1. Agustina C, Hadi H, Widyawati MN. Aromatherapy Massage as an Alternative in Reducing Cortisol Level and Enhancing Breastmilk Production on Primiparous Postpartum Women in Semarang. ASEAN/Asian Academic Society International Conference Proceeding Series; 2016.

2. Alexander EK, Pearce EN, Brent GA, Brown RS, Chen H, Dosiou C, et al. Guidelines of the American Thyroid Association for the diagnosis and management of thyroid disease during pregnancy and the postpartum. Thyroid. 2017;27(3):315-89.

3. Arikunto S. Research Procedure, A Practice Approach. Jakarta: Rineka Cipta; 2002.

4. Boelig RC, Barton SJ, Saccone G, Kelly AJ, Edwards SJ, Berghella V. Interventions for treating hyperemesis gravidarum. The Cochrane Library. 2016.

5. Chan J, Chien W. A Randomised Controlled Trial on Evaluation of the Clinical Efficacy of Massage Therapy in a Multisensory Environment for Residents with Severe and Profound Intellectual Disabilities: A Pilot Study. Journal of Intellectual Disability Research. 2017;61(6):532-48.

6. Depkes RI. Health Profile of Indonesia 2008. Jakarta: Depkes RI; 2008.

7. Finer LB, Zolna MR. Declines in Unintended Pregnancy in the United States, 2008-2011. New England Journal of Medicine. 2016;374(9):843-52.

8. Frawley J, Sibbritt D, Steel A, Chang S, Adams J. Complementary and Conventional Health-care Utilization Among Young Australian Women With Urinary Incontinence. Urology. 2017;99:92-9.

9. Heath S. Methods, Products, and Systems Relating to Making, Providing, and Using Nanocrystalline (nc) Products Comprising Nanocrystalline Cellulose (ncc), Nanocrystalline (nc) Polymers and/or Nanocrystalline (nc) Plastics or other Nanocrystals of Cellulose Composites or Structures, in Combination with other Materials. Google Patents; 2016.

10. Heitmann K, Solheimsnes A, Havnen GC, Nordeng H, Holst L. Treatment of Nausea and Vomiting During Pregnancy- a Cross-sectional Study among 712 Norwegian Women. European Journal of Clinical Pharmacology. 2016;72(5):593-604.

11. Holmes P. Aromatica: A Clinical Guide to Essential Oil Therapeutics. Volume 1: Principles and Profiles: Singing Dragon; 2016.

12. Liu CH, Snidman N, Leonard A, Meyer J, Tronick E. Intra-individual Stability and Developmental Change 
in Hair Cortisol among Postpartum Mothers and Infants: Implications for Understanding Chronic Stress. Developmental Psychobiology. 2016.

13. Lochmann KA, Grossman A, Ebert C, Gatton C. Aromatherapy as Symptom Management for Hematology/Oncology/Blood and Marrow Transplant Patients. Biology of Blood and Marrow Transplantation. 2017;23(3):S477.

14. Malek NZH, Kalok A, Hanafiah ZA, Shah SA, Ismail NAM. Association of Transient Hyperthyroidism and Severity of Hyperemesis Gravidarum. Hormone Molecular Biology and Clinical Investigation. 2017.

15. Marquis M, Francis EA. Witchy Mama: Magickal Traditions, Motherly Insights \& Sacred Knowledge: Llewellyn Worldwide; 2016.

16. Mezzoug N, Idaomar M, Baudoux D, Debauche P, Liemans V, Zhiri A. Genotoxicity of Some Essential Oils Frequently Used in Aromatherapy. Advances in Bioscience and Biotechnology. 2016;7(02):63.

17. Muchtaridi M,Tjiraresmi A, Febriyanti R. Analysis of Active compounds in Blood plasma of mice After inhalation of Cajuput essential oil (Melaleuca Leucadendron L.). Indonesian Journal of Pharmacy. 2016;26(4):219.

18. Mukherjee S, Ross PWA. Nausea and Vomiting in Pregnancy. The McGovern Medical School Journal of Medicine. 2017:7.

19. Depkes RI. Basic Health Research 2007. Jakarta: Depkes RI; 2007.

20. Senturk MB, Yıldız G, Yıldız P, Yorguner N, Çakmak Y. The Relationship between Hyperemesis Gravidarum and Maternal Psychiatric Well-being during and after Pregnancy: Controlled Study. The Journal of Maternal-Fetal \& Neonatal Medicine.2017;30(11):1314-9.

21. Takemoto H, Nishimura J, Komori T, Kim HM, Ota H, Suzuki R, et al. Combination Antiemetic Therapy with Aprepitent/fosaprepitent in Patients with Colorectal Cancer Receiving Oxaliplatin-based Chemotherapy in the SENRI Trial: Analysis of Risk Factors for Vomiting and Nausea. International Journal of Clinical Oncology. 2017;22(1):88-95.

22. Thanaboripat D, Sarutipaisan C, Puangtong C, Chatpongsatorn P, Suvatti Y, Sukonthamut S, et al. Effects of Four Essential Oils on the Growth of Aflatoxin Producing Fungi. KMITL Science and Technology Journal. 2017;16(2).

23. Vrishabhendraiah APDSS, Jayadevappa RDSB. Psycho-Aromatherapy: A Review. Issues. 2017;2016:2015.

24. Westerlund A, Vicente V, Judell OH, Lindström V. Preventing and Alleviating Patients' Symptoms of Nausea and Vomiting while in the Care of the Ambulance Service-a Qualitative Study. International Emergency Nursing. 2016;28:34-8. 